\title{
A CHALLENGE POSED BY POSTMODERNITY: FROM IDOLATROUS FASHION TO IDOLIZING FASHION
}

David PESTROIU*

\begin{abstract}
As the secularized man has developed a postmodern mindset, the concept of Luciferic individualism acquired an autarchic evolution, keeping up with the postulate formulated by Paul Lakeland, who foresaw the escalation of demonic influence on the world, accompanying the emancipation characteristic of the advanced society ${ }^{1}$. Idolizing the self has become a true "fashion", generating further idolatry of stars, sports, various types of entertainment, or even one's work or profession. Fashion itself is an idol: one cannot be "cool" unless one is "trendy".

The present study aims to investigate the factors accounting for this status quo, and provide possible missionary solutions, from the perspective of Orthodox missiology.
\end{abstract}

Key words: postmodernity, fashion, idol, challenge, idolatry

\section{Postmodernity as a concept}

The defining frameworks of postmodernity and the ways they influence human development have been talked about quite a lot lately. It is obvious that we are witnessing an astonishing emancipation: elements which lead to the widespread installation of comfort equally destroy the old landmarks defining human existence. The autarchic model of selfhegemony begins to take shape more and more significantly. The postmodernist individualism launches the great social challenge to the ecclesial community ethos. In a world that worships selfishness, what

\section{*PhD, University of Bucharest, Faculty of Orthodox Theology, București, Romania.}

${ }^{1}$ Paul Lakeland, Postmodernity: Christian Identity in a Fragmented Age (Guides to Theological Inquiry Series), Minneapolis, Minnesota, Fortress Press, 1997, p. 89. 
dynamic will human relationships have?

To provide a possible answer, we must go deeper into our research on the constitutive springs of postmodernity. Especially helpful in this regard we consider Philip Sampson's study, The Rise of Postmodernity. Here, the author provides a synthetic vision, integrating the many definitions that were given to this concept:

"Like love in the popular song, postmodemity is a many splendoured thing. Some see it as characterising the mode of production of late capitalism (Jameson); others identify an entirely new mode of activity (Poster); some consider it to presage new creative possibilities (Winter), others see its influence as sinister (Diederichsen); some see it as an essentially new condition (Lyotard), others doubt its existence (Rose), or consider that it articulates the position of dispossessed intellectuals (Bauman)"2.

Postmodernism suggests both new types of enlightenment and humanism. Totally separated from religion, these articulate exclusively on a secular background as backlash against traditionalism and unreservedly embrace all that is new, cosmopolitan, developed on science and technology. It's the time of categorical denunciation of any form of institutionalized hierarchy; the primacy of the majority itself, which should be at the core of any democracy, is shaken by the noisy claims of minority rights. The postmodern man reinvents himself when, on behalf of his emancipation, he reveals himself as the Demiurge, idol of his own vanity. The personal existence of the Christian God, revealed in the Scripture and the Sacred Tradition, is widely disputed as long as its communication channels are blocked by the low state individual man, unable to relate beyond its instinctual mundane struggles. In this regard, the famous definition given by Jean-Francois Lyotard to postmodernism, as being the incredulity towards meta-narratives ${ }^{3}$, finds its logical explanation: traditional answers to the great existential questions, based on biblical revelation, are obsolete, as they must make place for new

${ }^{2}$ Philip SAMPSON, “The rise of postmodernity”, in Philip Sampson (ed.), Faith and modernity, Oxford, Vinay Samuel and Chris Sudgen, Regnum Books International, 1997, p. 29.

3 Jean François LYOTARD, The Postmodern Condition: a report on Knowledge, Translation from the French by Geoff Bennington and Brian Massumi, Foreword by Fredric Jameson, Minneapolis, University of Minnesota Press, 1984, p. XXIV. 
explanations, of convenience, coming from secular humanism. Having as support the emancipatory message of reason, they highlight values such as goodness, truth, beauty, kindness, justice, in terms of their adaptation to the progress of science and technology, with direct reporting to the material comforts of this world, totally excluding the perspective of eternity and the cultivation of holiness.

"As Christians - states S. Grenz, 'Ale claim to know what that grand narrative is. It isthe story of God's action in history for the salvation of fallen humankind and the completion of God's intentions for creation. We boldly proclaim that the focus of this metanarrative is the story of Jesus of Nazareth, who, we testify, is the incarnate Son, the second Person of the triune God"4.

In fact, postmodern man does not want to solve the equation of existence. Living, exclusively contingent, consumed by the present time, excludes the postulating of the transcendent sense of life. Therefore, he is tense and confused, and often oscillating between different philosophical systems, elements of syncretic thinking, SF novels or his own phantasmagoric visions. From this view, postmodernism is presented as a lost certainty or a conscious ignorance ${ }^{5}$.

Despite all the claims of creating a perfect society, the secular humanists have registered failure on all levels, which shows that, although their intentions seem good in appearance, in reality they are impractical. Individualism, based on vanity and egoism, has led to the impossibility of achieving emancipation in society and politics. Lack of cultivating communion and self-centered turmoils lead, in fact, to fragmentations deeper than those of modern times, that postmodernity had the pretention of correcting. To correct the flares of the individualistic manifestations, a rule of fashion was introduced: being trendy is a must: it is how the members of society are brought to the same common denominator.

Nor are the conquests of science and technology more convincing, in reality. Their uses in the weapons industry or the crisis caused by

${ }^{4}$ Stanley J. GRENZ, A primer on postmodernism, William B. Eerdmans Publishing Company, Grand Rapids, Michigan / Cambridge, U.K., 1996, p. 164.

${ }^{5}$ R. WinTEr, "Postmodern Sociology as a Democratic Educational Practice? Some Suggestions”, inBritish Journal of Sociology of Education,no.12(4)/1991, p. 471. 
pollution are painful realities for the millenial man. Even if there has been a pleiade of environmental and pacifist movements, which offer various programs and projects - themselves large consumers of resources - the results are yet to be seen.

In terms of communication, things are, perhaps, the most dramatic. There hasn't been, throughout the history of humanity, a subtler form of subjugation of reason and mind control than the one looming before our own eyes, in postmodernity. Hypnotized by social networks, nailed watching the TV, man lives an acute drama of depersonalization. He is no longer allowed to even dare to think freely; in fact, he no longer needs to: others do it for him. Gross manipulations spread their tentacles upon him with no reaction from him in any way. He credits so easily vicious sources of information, that it is not hard to shape his sleeping consciousness. It is enough just to stimulate his false emancipation: in other words, it is enough if he is offered the impression that the speech belongs to him, that he draws the conclusion himself (induced subtly, of course), that he is the single and most able to make valuable judgments on any topic, whether he has any competence in the field or not. In this sense, blogs are a very good research topic: all comments are made from the position of experts, but under a lucid analysis, their posts are nothing but the viralization of manipulation, sometimes of true epidemic proportions. Under the mask of emancipation lies, in fact, a hard labour.

Socially, postmodern emancipation has dramatic accents. Under the guise of freedom and the praised 'human rights', creating new social polarizations, meant to destroy the very foundations of traditional affiliations. Contesting movements against traditional churches arise, accused of the fact that they are unable to keep up with postmodern fashion. Starting from the anti-racist and anti-slavery movements in the West, Romanian Orthodoxy is the target of unprecedented attacks, aimed at putting the blame on it because of the maintenance of gypsies in slavery until the middle of the nineteenth century, but also because of the use of liturgical phrases like: slave / servant of God. Feminist movements, with events of emancipation, with clear pro-abortion guidelines advocate inclusively the priestly duties of Western religions. Contraception and family planning are gaining more and more followers, as well as hybrid forms of cohabitation: concubinage, consensual unions or civil partnerships - all designed to dig at the root of the traditional family. 
Obviously, the same goal pledged movements promoting LGBT rights, engaging a huge manipulative force from the West: meetings with shameless exhibition of these anomalies, involving members of the diplomatic corps of prestigious countries, to "teach us a lesson", musical and cinematographic productions in which these minorities are present, giving the impression of 'normality', culminating with obvious rigging of artistic events of a great interest to the public, such as Eurovision, which became a real 'platform' that presents all kinds of sexual deviations.

While searching for Truth, which, according to Christianity, is one - Christ, humanity has gone through history with the belief of the uniqueness of this approach. In postmodernity, we find the idea that there is not just one truth, the plural truths being increasingly used, in the sense that each individual justifies himself before others, claiming his attitude as being prototypical. That is why Jürgen Habermas speaks of 'localization of truth' ${ }^{6}$. In this case, knowledge becomes itself a premise for consumerism, influenced by the forms of communication of the moment: Chat, Messenger, Facebook, Twitter, WhatsApp etc. Religions themselves are allowed only to the extent in which they cease to relate to their own dogma as unique and unmistakable truths. They are rejected as a whole: deep thoughts, mystical feelings, moral rigors - all being criticized as harmful to the practice of postmodern hedonism. Mediocrity and superficiality are established everywhere. Lack of depth becomes a general characteristic of contemporary society's mentality. Reality is converted into image, rendered by technical means of an exceptional clarity (3D, I-Max etc.) and thus distorted in the figurative plane, where manipulatory processing is commonplace. Many people, especially young people, isolate themselves in the virtual space created on the computer, where movies, games or regular TV productions are imbued with subliminal messages designed in order to create addiction. A special category is the eroticism industry that supplies the nervous centres of the brain with images meant to feed the impulses of the body in a desperate attempt to control the entire psycho-physical being of the individual by the continuous stimulation of pleasure. The same J. Habermas, speaking about the postmodern vision of the world, describes it as 'the triumph of

6 Jürgen Habermas, The Philosophical Discourse of Modernity, s.l., Polity, 1987. 
desire over reason ${ }^{7}$. Religions, cultures, traditions, ideologies, lifestyles are fragmented into a plurality, however homogeneous, to the extent in which it suggests itself and is claimed to be based on relativism.

Thus, the entire story is deconstructed. Humanity lives a continuous present. The idea of transmigrational wanderings of each individual is powered in a time regarded as linear, with an obvious cyclic component. Illustrating this can be best seen in one of the most outstanding productions of postmodern cinema, Cloud Atlas. Past and present overlap and are projected into an uncertain future, as long as the present moment is intended to be made permanent. Talking about history, in this case, becomes impossible.

A new type of interaction is absolutely necessary: the network. Here, the exchange of information is fast, based on voluntary adherence and personal involvement. Communities move in cyberspace, being animated by common cultural patterns or by the skills of the network designers. The offer is huge, the traps just as manipulative. Unfortunately, the ecclesiastical institution has a discreet presence, even hesitant, in the social area which is in a clear expansion. We'd rather witness the polarization of pseudo-religious groups with extremist, fundamentalist manifestations, which seize attention with exuberance, sometimes even driven to aggression. And this is due to the fact that the keynote of the viral messages on these networks is victimization, dissatisfaction, oppression, exclusion of adherents, ready to proclaim themselves oppressed and claim rights, by virtue of self alleged truths, criticizing order, institutions or social structures, usually considered as downright obsolete.

Paradoxically, although it glorifies self in a self-sufficient manner, idolizing it, postmodernity quits the authentic search for it and its natural anchorage in the transcendent. "There is no subject in itself, but a subject on the shelf" take pride in self promotion, but without a real insight into its true dimensions, and, what is worse, by falsifying consciousness. In modernity, we witness a repositioning of values, structured hierarchycally, respecting the accumulation of knowledge or cultural

\section{${ }^{7}$ Ibidem.}

${ }^{8}$ Philip SAMPSON, "The rise of postmodernity", p. 29. 
ARS LITURGICA. From the Image of Glory to the Images of the Idols of Modernity

background, a true promotion of elites. Postmodernity, by attacking metanarratives, collapses hierarchies. Complex personalities are no longer fashionable, as culture no longer develops in depth, but at the surface, becoming a mass subject, subordinated to the same consumerist rules which situate populism above elitism. As consumers, people of today's society consider themselves as poly-qualified experts in all fields, loathing the true professionals. Of course, such a view is clearly intertwined with the ideals of democracy and political rectitude. As far as we are concerned, the principles of ecclesiastical organization are, once again, exposed as being outside the trend, as they obviously support a hierarchical stratification.

It is very interesting that, although it deconstructs metanarratives, postmodernity itself ends up creating its own narrative, of global proportions: the vision of the mediocre elite of consumerism which advocates the decentralization of knowledge, but gets to aestheticize the anarchy generated by the generalized spirit of contesting everything. And what would its main asset be? Excessive cultivation of pleasure as a result of mere sensations, of carnal experiences, which throw the mundane existence into an incredible effervescence of superficiality, thus illustrating the concept synthesized by J. Habermas in the expression "the aesthetization of life and morals" 9 . Obviously, we're talking about human life in the form of flesh, with no prospects ofeternity.

\section{Being fashionable - the expression of a new social restructuring}

In recent times, there has been a paradigm shift in terms of the emancipated human's activity in general. Industrial production has lowered in intensity, it moved largely in countries with emerging economies, rising consumption at an alarming rate, emphasizing subsequent economic branches: trade and services, with new directions developed accordingly: media, advertising, entertainment. It was not too far in the past when material goods were valued at their true value, being saved or even stored as food for the future (often uncertain); today they hardly represent anything but consumption resources and often symbols

9 Jürgen Habermas, The Philosophical Discourse of Modernity, Polity, 1987. 
of a huge waste. Contemporary man does not analyze the actual meaning of the goods availableany more, but how he can use them, consuming them quickly to generate the pleasure that he so desperately seeks. The predictability of an uncertain future ceased, postmodern hedonism resuming the ancient hedonistic thesis of "living the present moment" (carpe diem). Consequently, the issue of accumulating resources and saving no longer exists.

In support of such a mentality, the advertising industry has developed, supported by the media especially. Actual products turned into imaginary products, which are consumed not because of their necessity or their value to human life, but due to the manipulative effects of advertising. Sometimes these effects are meant to encourage dangerous practices (addictions to tobacco, alcohol, excess of sugar, etc.), but the huge financial interest is at peace with the human inclination to cultivate pleasure at any risks.

Gradually, in postmodernity, everything becomes an object of consumption. And to this process, new technologies contribute largely, focusing on the development of telecommunications, electronic computers, digitalization and industrial, economic and, especially, mediatic processes. Particular emphasis is placed on product design, which is required to adapt to the existing cultural patterns, in a continuous effort to promote the image and personal style to the community of consumers. The very scientific approach is shifted from the disinterested research, whose sole purpose is generating and seeding knowledge itself, to a real public policy, recalibrating the research based on the obvious managerial interests oriented towards the interest in material consumption and cultivation of pleasure.

According to P. Sampson, „From the high ground of modernity, such an information-based consumer culture is either sinister or superficial. Electronic surveillance and control extends its invisible hand over the lives of individuals and communities. The simulational world of spectacle, experience and consumption provides a new opiate of the people with Disneyesque nostalgia, shopping malls and theme parks; Las Vegas style rules OK"10.

${ }^{10}$ Philip SAMPSON, “The rise of postmodernity”,p. 31. 


\section{Why is fashion idolatrous in postmodernity?}

I have already mentioned above that postmodernism has established that being fashionable is its representative value. And the defining element of fashion is excessive waste of matter in order to achieve pleasure. Consequently, scientific reflection and academic research are gradually recalibrated. From activities initially designed to take place on their own, leading to spectacular and unpredictable results, they have turned into routine and predictable teamwork, irremediably damaging the free personalist thinking, to what $\mathrm{Z}$. Bauman calls "the implosion of intellectual vision" ${ }^{\text {"11 }}$.

"As citizens become consumers, integrated into society by the seductions of the market, and able to participate directly in political policy through technological innovation, representative democracy becomes a minority interest for those who are excluded from the market, for the oppressed, the poor" ${ }^{\prime \prime}$.

Fashion idolatry means developing a cult. From the 'catacombs' of consumerism represented by small boutique shops, postmodern architecture has been reshaped, creating true 'temples' of trade: shopping malls ${ }^{13}$ and supermarkets, which bring together a multitude of ways of material waste, whose only common factor is to be trendy. Everything sold here is not necessarily the result of a qualitative choice, but a clear need: that of a reconciliation between compressed time and the greed for success of the advertising industry. There is, paradoxically, a category of 'spiritual goods' offered at the mall: display units of several new religious movements, all which work on the same principle: if advertising is visible, the success is guaranteed. There are voices which state that even the Church, in an aggiornated form, should also be present there, but, equally, there is serious opposition to the risk of compromising the evangelical message. Church itself should not become another shopping

${ }^{11}$ Z. BAUman, "Is there a postmodern sociology?", inTheory, Culture \& Society,no. 5(23)/1988, p. 219.

${ }^{12}$ Philip SAMPSON, "The rise of postmodernity",p. 43.

${ }^{13}$ Pete WARD, God at the Mall: Youth Ministry that Meets Kids where They're, s.l., Hendrickson, 1999. 
center, offering faith in accordance with the market. It has preached, during its bi-millennial existence, a set of teachings and rules; most of them uncomfortable and even hostile to hedonistic expectations, whatever form might they have taken.

\section{Becoming a star: the luciferic seduction}

For the postmodern man, Lucifer's drama becomes his own source of permanent existential angst. Self-deification, unrealized in fact, leads to a state of constant frustration and hiding reality. It creates a state of rebellion against God, and, especially, loads an insatiable desire to challenge His commandments. Thus, the very idea of final Judgment and restoration of the universal order is denied. Interest in earthly life prevails, lived in continuous entertainment, without the perspective of eternity. At most, as a concession to the postmodern religious syncretism, the more lax vision promoted by Eastern religions is embraced: the idea of successive reincarnations increasingly takes shape, but not as a later accountability, but as the extension of earthly hedonistic living. Thus, the idea of an immortal soul and its sustainability after the death of the body acquires new meanings. Postmodern man is no longer interested in the prosperity of his soul, spiritual enhancement, cultivation of virtues or inner transformation of the individual, directed not to the material consumption, but to eternity. In this sense, P. Sampson noticed very well: "In postmodernity this search for an inner self is abandoned. There is no inner self to find, no essence from which to be alienated ${ }^{14}$ ".

From the Beatles' famous statement that they would have exceeded the popularity of Jesus Christ, we witness a real hysteria of the idolatry of stars and even music genres themselves. Obviously, we are not referring to religious, folk or classical music, but to those music trends that took hold of young masses, increasingly growing wider, creating a whole industry of endless fun. The creator of the first 'rock'n roll church' in California, Joel Agnew, believes rock music is an 'alternative religion' to 'all the other miseries' ${ }^{15}$. Nina Hagen has considered herself 'God's channel', and the Rolling Stones and Ozzy Osbourne spread musical

${ }^{14}$ Philip SAMPSON, "The rise of postmodernity", p. 43.

${ }^{15}$ Nicolae ACHIMESCU, Religie, modernitate și postmodernitate, București, Trinitas, 2013, p. 258. 
creations with demonic titles and content. A special dimension consists of some extreme forms of rock, which become downright satanic. Inspired by African religiosity, these forms combine an aggressive and loud melody with spasmodic movements of the body in a manner similar to the tribal witchcraft rituals. If we add up the content of the text accompanying these songs, we have a complete picture of insults to God, as $\mathrm{He}$ is perceived by traditional religions, combined with satanic and luciferic eulogies. All these compromised songs equally promote a new type of cultural language, in which signs and symbols, that need to be deciphered after a continuous struggle of self-assertion, occupy the place of honour. Graffiti techniques are eloquent examples of this language, creator of its own identity, says P. Sampson:

'Literature, music and film present instances of postmodern identity (for example William Burroughs / David Cronenberg, David Bowie, David Lynch), but the exemplary case of a self presenting a range of identities or performances is provided by Madonna, who draws on a multiplicity of representations, from Material Girl, creator of her own sexuality through, to the vulnerability of Monroe ${ }^{\text {16 }}$.

Celebrities from absolutely all areas of public exposure add to the categories listed above. From politicians to members of some sports teams, all suggest themselves as idols to followers, supporters and fans. Let us remember that stadiums have lately been considered temples and their audiences make offerings to the "football gods" ${ }^{17}$. Not even the religious field is excluded from this plague: a wide and diverse range of masters, wise gurus, initiators of new movements and religions, therapists, shamans etc. are propelled into the spotlight, generating real hysteria in the form of trends usually known as 'spiritual alternatives" 18 .

Stanley J. Grenz, in his excellent book: A primer on postmodernism, states: "Living in a postmodern society means inhabiting a film-like world - a realm in which truth and fiction merge. We look at the world in the same way we look at films, suspicious that what we see around us may in fact be an illusion. Despite a film's disjunctions,

${ }^{16}$ Philip SAMPSON, “The rise of postmodernity", p. 45.

${ }^{17}$ David Pestrolu, "Misiunea Bisericii Ortodoxe în postmodernitate", in Theologia Pontica, no.1/2009, p. 133.

${ }^{18}$ Radu Petre MureșAn, Alternative spirituale în România, Sibiu, Agnos, 2011. 
however, the viewer can at least be certain that it expresses something about the minds that produced it; the filmmaker provides an often unattended center to the world the film creates. Looking at the world, on the other hand, postmodernists are no longer confident that any Mind lies behind it" ${ }^{\prime \prime}$.

\section{Between disappointment and hope. Technology information as a dimension of ecclesial mission}

Pam Smith suggests that mission could be improved by online connections. Let us take note of a fragment of her practical research, Online mission and ministry: "One of the most pressing worries for the church in the West is the numerical decline in membership. This is largely seen as a consequence of the shift from 'Christendom' - when Christianity was politically and culturally dominant - to 'postmodernity' where no one worldview or set of ideals is seen as overarching. Given these worries about the declining influence of Christianity, it might be supposed that new ways of connecting people with the gospel would be welcomed. Yet as numbers decline, new forms of ministry can, instead, attract opposition from Christians who feel more effort should be invested in strengthening the missional effectiveness of the inherited church rather than dissipated into new and untried models. It is assumed that, by enabling people to participate in Christian community via their electronic communication devices, we are discouraging them from participating in Christian activities offline. Experience suggests the opposite - most online Christian communities have found that participants tend to become more, not less, interested in exploring and expressing their faith offline as a result of their involvement online" 20 .

Postmodern society has developed at odds, in the past unimaginable, a true culture of information ${ }^{21}$. Based on technological empowerment, news travel everywhere with the speed of online

${ }^{19}$ Stanley J. GRENZ, A primer on postmodernism, William B. Eerdmans Publishing Company, Grand Rapids, Michigan / Cambridge, U.K., 1996, p. 33.

${ }^{20}$ Pam SMith, Online Mission and Ministry. A theological and practical guide, Society for Promoting Christian Knowledge, Ashford Colour Press, London/Hong Kong, 2015, p. 18.

${ }^{21}$ Hervé CARRIER, S.J., Evangelizing the Culture of Modernity, New York, Faith and Culture Series, Orbis Books, Maryknoll, 1993. 
broadcasting waves. Internet, television and radio enable fast and direct communication, but also the danger of manipulation. Idolatrous fashion came here also. We now witness the crediting, without discernment, of some TV presenters or opinion makers in the media or the online field, or frequent cases when mere adherence to social networks creates multiple polarizations around targets whose importance is overrated, which turn into large scale advertising campaigns, based on occult interests and abundantly funded. Our attention has been drawn recently to a highly aggressive campaign against Orthodox places of worship, the number of hospitals being compared to that of cathedrals. Mystification, cleverly devised, weighed entities and values that are quite different, both in terms of purpose and of the number of beneficiaries. In the category of 'hospitals', the dispensaries or clinics were not inventoried, instead, in the 'cathedral' category, all places of worship were listed, including chapels belonging to all recognized religions, although the revolt was obviously directed against Orthodoxy. Such gross manipulation succeeded, however, to draw tens of thousands of followers in the online field, also developing a violent side of aggressive public protests and marches and some unauthorized rallies.

The disclosure of such attacks and manipulations is not enough, especially if they have already made deep furrows in the collective mentality. It takes a formidable missionary work for the prevention of these phenomena. Awareness of the dangers that the exposure to some image vulnerabilities can present should be raised. However, modern communication technologies offer new opportunities of presenting the Bible and also new ways in which the church puts into practice the entire pastoral and social-philanthropic message of Jesus Christ for the world's and man's restoration. It is the call to exit the contingency of a superficial, materialistic and consumerist life. It is finding the true meaning of existence: communion with God in the eternal kingdom of The Holy Trinity's love.

\section{References:}

1. ACHIMESCU, Nicolae, Religie, modernitate și postmodernitate, București, Trinitas, 2013;

2. Bauman, Z., "Is there a postmodern sociology?", in: Theory, Culture 
\& Society, no.5(2-3)/1988;

3. CARRIER, Hervé S.J., Evangelizing the Culture of Modernity, New York, Faith and Culture Series, Orbis Books, Maryknoll, 1993;

4. Bennington, Geoff / MASsumi, Brian, Foreword by Fredric Jameson, Minneapolis, University of Minnesota Press, 1984;

5. GRENZ, Stanley J., A primer on postmodernism, William B. Eerdmans Publishing Company, Grand Rapids, Michigan / Cambridge, U.K., 1996;

6. Habermas, Jürgen, The Philosophical Discourse of Modernity, s.l., Polity, 1987;

7. LaKeland, Paul, Postmodernity: Christian Identity in a Fragmented Age (Guides to Theological Inquiry Series), Minneapolis, Minnesota, Fortress Press, 1997;

8. LYOTARD, Jean François, The Postmodern Condition: a report on Knowledge, Translation from the French by Geoff Bennington and Brian Massumi, Foreword by Fredric Jameson, Minneapolis, University of Minnesota Press, 1984.

9. MuREȘAn, Radu Petre, Alternative spirituale în România, Sibiu, Agnos, 2011.

10. Pestrolu, David, „Misiunea Bisericii Ortodoxe în postmodernitate”, în: Theologia Pontica, no. 1/2009;

11. SAMPSON, Philip, "The rise of postmodernity", in: Philip Sampson (ed.), Faith and modernity, Oxford,Vinay Samuel and Chris Sudgen, Regnum Books International, 1997;

12. SMith, Pam, Online Mission and Ministry. A theological and practical guide, Society for Promoting Christian Knowledge, Ashford Colour Press, London/Hong Kong, 2015.

13. WARD, Pete, God at the Mall: Youth Ministry that Meets Kids where They're, s.l., Hendrickson, 1999.

14. Winter, R., "Postmodern Sociology as a Democratic Educational Practice? Some Suggestions", in British Journal of Sociology of Education, no. 4/1991. 